\title{
EXTERNAL SPHINCTEROTOMY: RATIONAL FOR THE PROCEDURE AND EXPERIENCES WITH I5O PATIENTS
}

\author{
By Paul F. Schellhammer, Robert H. Hackler and R. Carl Bunts \\ From the Urological Section, Surgical Service, McGuire Veterans \\ Administration Hospital, Richmond, Virginia
}

EXTERNAL sphincterotomy is an endoscopic technique intended to restore effective voiding capacity to the neurogenic bladder by decreasing urethral resistance and thereby eliminating the need for indwelling catheter drainage. Its effectiveness in providing a balance between the expulsive forces of the neurogenic bladder and those forces offering resistance to micturition has been clinically demonstrated (Ross et al., I958a and $b$ ). The first external sphincterotomy at this large cord injury centre was performed in 1966. Since that time 236 sphincterotomies have been performed on 216 patients. This report will evaluate the results of 173 procedures in 150 patients who were available to recent follow-up.

\section{MATERIALS AND METHODS}

The results of our first series of 85 external sphincterotomies were reported by Currie et al. in I968. We have continued to follow these patients and now report the results in an additional 75 patients. We have included in this report only those patients who have been evaluated since I January 1972.

After the spinal shock phase of injury and the permanency of the neurologic defect has been established, the patient is given a voiding trial. If urinary retention or a post-void residual greater than 30 per cent. of bladder capacity ( $90 \mathrm{cc}$. maximal) results, the patient is evaluated for external sphincterotomy. In addition, an intravenous pyelogram, cystoscopy, cysto-urethrogram, cystometrogram and sphincterometrogram are obtained. External sphincter pressures, or more correctly retrograde urethral pressures, are determined by the method described by Currie et al., I970 (Fig. I).

Sphincterotomy is performed with the McCarthy resectoscope fitted with a knife electrode (Fig. 2). The cutting loop is not recommended due to the increased incidence of severe haemorrhage when it is used. Incisions are made laterally at three and nine o'clock through the sphincter from a point just proximal to the verumontanum and extending through the external sphincter to the proximal bulbous urethra. The incisions are made with several passages of the electrical cutting knife gradually incising to a depth of a least $6 \mathrm{~mm}$. (fig. 3). Bleeding is controlled with point electrocoagulation. An incision at six o'clock along the ventral urethra was used in the initial two cases. It resulted in severe haemorrhage and is contra-indicated. The prostatic fossa is carefully inspected after the sphincterotomy incisions are made. The lateral undercutting of the distal prostate may result in an inward collapse of the lateral prostatic lobes. In several cases an unsuccessful sphincterotomy was corrected by resection of this collapsed prostatic tissue. Post-operatively a No. 22 three-way Foley catheter is left in place for 7 days. If irrigations are clear within 48 hours a smaller No. I6 Foley 
is used to replace the large bore catheter. After removal of the catheter a residual which is less than one-third of the total bladder capacity ( $90 \mathrm{cc}$. maximal) is considered as indicative of a successful result. The patient is followed at least yearly with residual urine measurement and intravenous pyelogram.

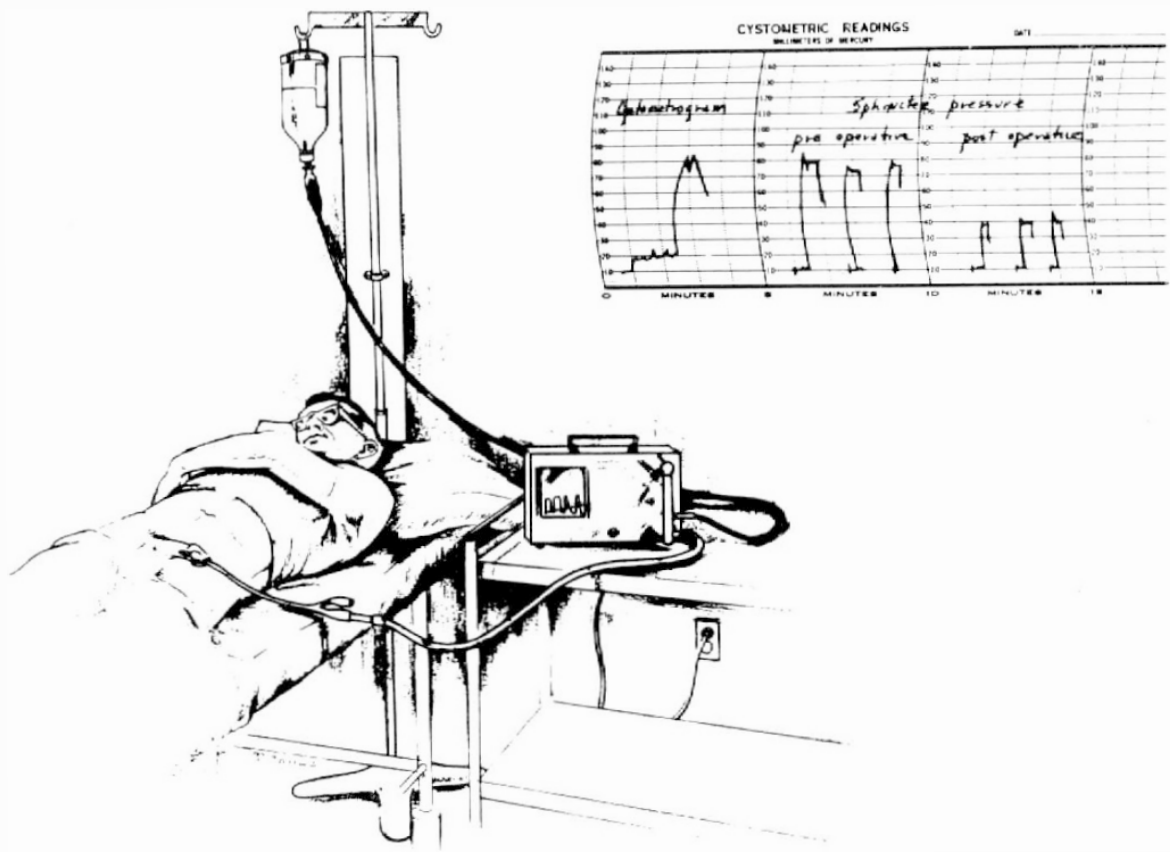

FIG. I

Method for determining retrograde urethral pressure as described by Currie. Sphincterogram demonstrating elevated pre-operative and lowered post-operative sphincter pressures shown in inset.

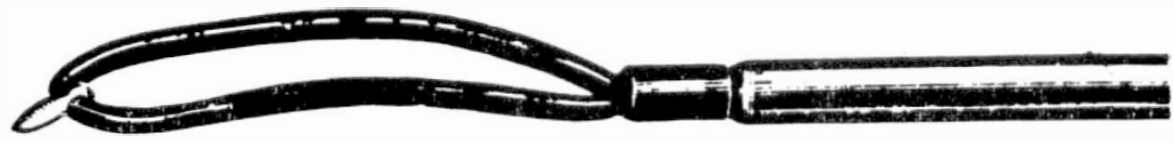

FIG. 2

Knife electrode.

\section{RESULTS}

In III patients (74 per cent.) sphincterotomy was successful in lowering resistance to voiding so that the amount of post void residual urine was negligible (Table I). Forty-nine of these patients have been followed from 3 to 5 years, 40 from 1 to 3 years and 34 from 2 to 12 months. The specific purpose of surgery, elimination of the indwelling catheter, was accomplished in IOI of these patients. The other Io still required catheter drainage for several reasons (Table II). 
Of the IIo patients with reflex bladders, 95 (68 per cent.) had successful results. In contrast, of the 40 patients with non-reflex bladders, only I5 (38 per

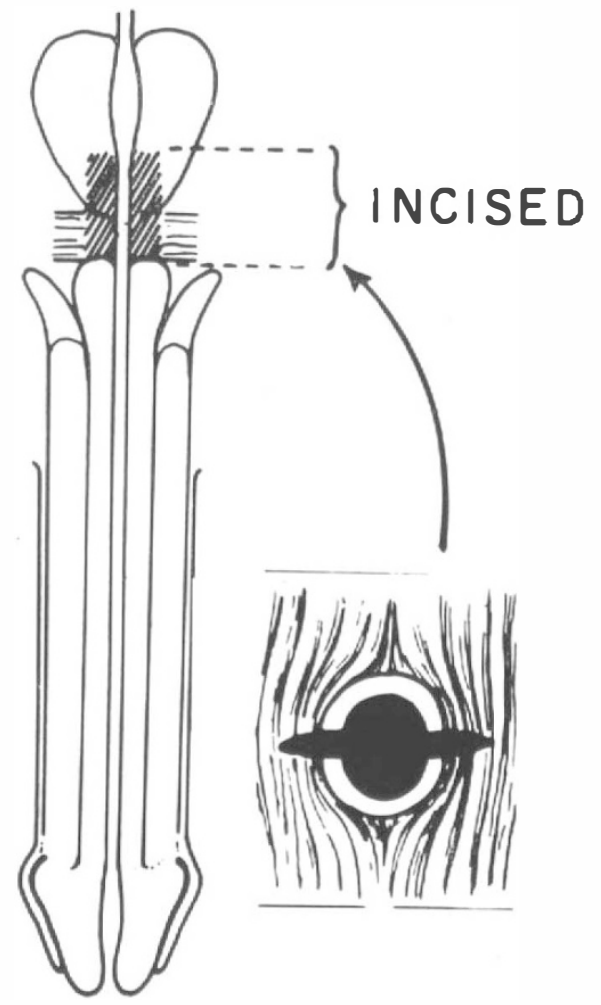

FIG. 3

Coronal and cross sectional views illustrating the extent of the sphincterotomy incision.

\section{TABLE I}

Results based on the level of cord injury

\begin{tabular}{|l|c|c|c|}
\hline & & \multicolumn{2}{|c|}{ Failure-39 $26 \%)$} \\
\cline { 3 - 4 } Level of lesion & Success - I I I $(74 \%)$ & $\begin{array}{c}\text { Initial } \\
\text { success-20 }\end{array}$ & $\begin{array}{c}\text { Persistent } \\
\text { failure-I9 }\end{array}$ \\
\hline Cervical & 43 & I I & I I \\
Thoracic & 4 I & 7 & 5 \\
Lumbosacral & 27 & 2 & 3 \\
\hline
\end{tabular}

cent.) had a successful result (Table III). Therefore an important factor for predicting surgical success is the condition of the bladder. We define a reflex 
bladder as one which exhibits a forceful detrusor contraction as demonstrated by cystomatrography. A non-reflex bladder shows either a flat curve or a curve with gradually increasing pressures but with no reflex voiding contraction. The cause of a non-reflex bladder in an upper motor neuron lesion may be due to inhibition of the reflex arc in the stump of the cord, or due to significant injury or degeneration in the cord below the uppermost motor and sensory level.

\section{TABLE II}

Catheter dependent after successful sphincterotomy

$\begin{array}{ll}\text { Short penis } & 3 \\ \text { Allergy to material } & 2 \\ \text { Vesico-ureteral reflux } & 2 \\ \text { Decubitus } & 2 \\ \text { Convenience } & \text { I }\end{array}$

TABLE III

Results based on bladder function

\begin{tabular}{|l|c|c|}
\hline & $\begin{array}{c}\text { Reflex bladder } \\
\text { I I0 patients }\end{array}$ & $\begin{array}{c}\text { Non-reflex bladder } \\
40 \text { patients }\end{array}$ \\
\hline Success & $95(86 \%)$ & $\begin{array}{c}\text { I } 5(38 \%) \\
(62 \%)\end{array}$ \\
\hline Failure & I5 (14\%) & $25(62 \%)$ \\
\hline
\end{tabular}

\section{TABLE IV}

Comparative values of pre-operative and post-operative sphincter pressures

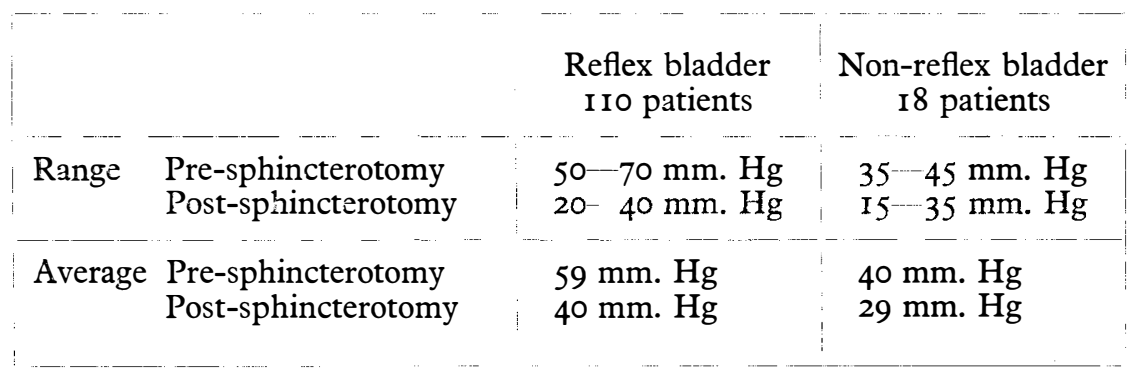

Pre-operative sphincter pressures in patients with successful sphincterotomy were higher than maximum bladder pressure in one-third of the patients, equal in one-third and lower in one-third. In this last group, the sphincter pressures, although lower than cystometrogram pressures, were still higher than normal. Pre- and post-operative sphincter pressures were available in 128 patients (Table IV). Reflex bladders were present in I IO patients, non-reflex bladders in 18 patients. In the reflex group there was an average decrease in retrograde urethral pressures of $19 \mathrm{~mm}$. mercury. Pressures ranged from 50 to $70 \mathrm{~mm}$. mercury 
pre-sphincterotomy to 20 to $40 \mathrm{~mm}$. mercury post-sphincterotomy. In the nonreflex bladders the average decrease in pressure was I I mm. mercury. Pressures ranged from 35 to $45 \mathrm{~mm}$. mercury pre-operatively to 15 to $35 \mathrm{~mm}$. mercury post-operatively. Regardless of the level of spinal cord damage, the retrograde urethral pressure in the post-operative period was decreased as compared with the pre-operative level.

We divided our failures into one group which demonstrated an initial success period from I month to I year post-sphincterotomy and another group which were immediate and persistent post-operative failures. These two groups were

\section{TABLE V}

Analysis of failures based on both bladder condition and spinal cord injury level

\begin{tabular}{|c|c|c|c|c|}
\hline & \multicolumn{4}{|c|}{ Failure-39 } \\
\hline & \multicolumn{2}{|c|}{ Persistent failure - I 9} & \multicolumn{2}{|c|}{ Initial success -20} \\
\hline & $\begin{array}{c}\mathrm{C}_{4}-\mathrm{T}_{2} \\
\text { Cervical-high } \\
\text { thoracic }\end{array}$ & $\begin{array}{l}\mathrm{T}_{3}-\mathrm{L}_{5} \\
\text { Thoraco- } \\
\text { lumbar }\end{array}$ & $\begin{array}{c}\mathrm{C}_{4}-\mathrm{T}_{2} \\
\text { Cervical-high } \\
\text { thoracic }\end{array}$ & $\begin{array}{l}\mathrm{T}_{3}-\mathrm{L}_{5} \\
\text { Thoraco- } \\
\text { lumbar }\end{array}$ \\
\hline $\begin{array}{l}\text { Reflex bladder } \\
\text { Non-reflex bladder }\end{array}$ & $\begin{array}{r}2 \\
10\end{array}$ & 7 & $\begin{array}{l}8 \\
3\end{array}$ & $\begin{array}{l}4 \\
5\end{array}$ \\
\hline
\end{tabular}

TABLE VI

Results of 2 I multiple sphincterotomies based on bladder function

\begin{tabular}{|c|c|c|c|c|}
\hline & \multicolumn{2}{|c|}{ Success-I5 } & \multicolumn{2}{|c|}{ Failure -6} \\
\hline & \multicolumn{2}{|c|}{ Number of procedures } & \multicolumn{2}{|c|}{ Number of procedures } \\
\hline & Two & Three & Two & Three \\
\hline $\begin{array}{l}\text { Reflex bladder } \\
\text { Non-reflex bladder }\end{array}$ & $\begin{array}{r}\text { IO } \\
3\end{array}$ & $\begin{array}{l}\text { I } \\
\text { I }\end{array}$ & $\begin{array}{l}\text { I } \\
5\end{array}$ & $\begin{array}{l}0 \\
0\end{array}$ \\
\hline
\end{tabular}

then analysed as to the level of the lesion and the condition of the bladder. Table I shows that the initial success group and the persistent failure group were similarly distributed between cervical, thoracic and lumbosacral lesions. However, Table V shows that in the group with the initially successful sphincterotomies, I 2 possessed reflex bladders and eight non-reflex bladders. This is in contrast to the total failure group where only two bladders were of the reflex type.

Twenty-one patients underwent repeated procedures due to an initial or late failure. Thirteen of the I9 secondary procedures were successful. In two patients three procedures were necessary before success was achieved. On three occasions, after an unsuccessful post-operative result in a repeat sphincterotomy, cystoscopy 
revealed inward collapse of prostatic tissue. Resection of this tissue resulted in satisfactory bladder emptying. Analysing the bladder condition in the procedures that were successfully repeated, it is noted that the majority, I I of I5, had reflex bladders (Table VI). This pattern again demonstrates that a reflex bladder will yield a higher rate of successful catheter-free voiding post-sphincterotomy.

In the successful sphincterotomy group (I I patients), 30 had undergone previous unsuccessful procedures for the purpose of lowering urethral resistance (Table VII). Most of these procedures were transurethral resections of the bladder neck.

\section{TABLE VII}

Unsuccessful procedures in patients who subsequently underwent successful external sphincterotomy

I. Transurethral resection of bladder neck 19

2. Multiple transurethral resections of bladder neck

3. Open bladder neck resection

Comparative cystograms before and after successful sphincterotomy showed that, of the 24 patients who had had bilateral or unilateral high pressure reflux pre-operatively, I4 no longer demonstrated reflux on either side post-operatively. Of the remaining Io patients intravenous pyelograms were stable in eight; two patients showed persistent deterioration of the upper tracts requiring conduit diversion.

External sphincterotomy is associated with very few complications and no mortality. Our most significant complication resulted from a severe prolonged haemorrhagic episode in one patient necessitating repeat cystoscopy for fulguration followed by suprapubic drainage and evacuation of clots to control haemorrhage. Four other patients required blood transfusion due to intra-operative and postoperative bleeding. Perineal extravasation occurred in one instance and responded to conservative therapy.

\section{DISCUSSION}

The primary urologic goal in the rehabilitation of a cord injury patient is to provide a mode of effective vesicle emptying in order that indwelling catheter drainage or surgical diversionary procedures can be avoided. The principal reason for ineffective voiding in the neurogenic bladder is imbalance between the expulsive forces of the detrusor muscle and the forces maintaining urinary continence. In most instances the upper motor neuron bladder will initiate reflex contractions. Vesicle emptying may be incomplete due to failure of the striated external sphincter and the pelvic floor musculature to relax. This spasticity of the external sphincter is the usual response of skeletal muscle to a lesion of the upper motor neuron. The lower motor neuron bladder usually lacks effective expulsive power and depends on manual external pressure or heightened intraabdominal pressure to empty. While the pelvic floor and external sphincter might offer a little resistance due to flaccidity, any area of resistance in the prostatomembranous urethra could significantly impede emptying when Crédé and/or increased intra-abdominal pressure are relied upon. 
That the imbalance between the forces of micturition and continence in a cord injury bladder may be surgically altered has long been recognised and diverse modes of decreasing infravesicle resistance to voiding have been employed. Emmett and Dunn advocated transurethral resection of the bladder neck to facilitate voiding (Emmett \& Dunn, 1946). Failure of this procedure, they stated, might be due to a hypertonic external sphincter, but they did not recommend division of the external sphincter as a primary procedure (Emmett et al., 1948). Efforts to decrease external sphincter spasticity have been directed at the uninhibited reflex arc innervating the striated muscles of the pelvic floor and the external sphincter. Alcohol block, pudendal neurectomy and sacral rhizotomy were designed to abolish the increased neuron input to these muscles. These procedures have met with varying success and carry the disadvantage of associated undesired neurologic defects. Other methods to decrease sphincter resistance include membranous urethrolysis and fatigue of the external sphincter by electrical stimulation.

More recently direct surgical attack on the area of abnormally increased urethral resistance has been employed. The exact location of this area is difficult to define due to multiple structures and factors which are important in maintaining urinary continence. They include the bladder neck, the external sphincter, the intrinsic urethral mechanism, the muscles of the pelvic floor, the coapting forces of the mucosa and the urethral length. The simplified mode of recording sphincter pressures used by us includes all these factors and actually represents retrograde urethral pressure and not solely external sphincter pressure. Other investigators (Emanuel, 1963; Lapides et al., 1960), have shown that the area of greatest resistance to voiding in the nerve intact individual lies in the membranous and distal prostatic urethra. Lapides established the urethral resistance at varying portions of the urethra and found them to be highest, average $57 \mathrm{~cm}$. water, in this area. Those pressures exceeded by $20 \mathrm{~cm}$. water the resistance in other areas of the urethra (Lapides et al., 1960). Ascoli (1967) and Damanski (I96I) have used cysto-urethrography to identify the membranous urethra as the point of obstruction to antograde flow of contrast media. The cysto-urethrograms reviewed in our study demonstrated similar findings. The bladder neck was open in patients with no history of prior bladder neck resection and the area of greatest narrowing was visualised at the prostato-membranous urethra. Our post-external sphincterotomy cysto-urethrograms demonstrated a widely patent prostato-membranous urethra as compared to the pre-operative X-rays. There seems to be little question that the site of greatest urethral resistance is in the prostato-membranous urethra.

In 1947 Donovan suggested destruction of the membranous urethra with a cold punch. A year later Baumrucker (1948), used electrocautery to destroy the membranous urethra. In I958 Ross et al. reported clinical success in eight patients in whom the external sphincter had been destroyed using a cold punch resectoscope. Two deaths occurred post-operatively. This was attributed to the poor condition of the patients and the excessive bleeding resulting from the cold punch technique. In a I0-year follow-up Ross et al. (1967), reported successful results in 60 of 65 patients who had undergone this procedure. Smythe, (I966), reported good results in seven of eight patients. O'Flynn (1972), obtained good results in 38 of 42 patients with external sphincterotomy. Neither author mentioned the length of their patients' follow-up. O'Flynn commented that the bladder neck obstruction seen in spinal cord injury patients was secondary to increased sphincter pressure 
initially causing detrusor hypertrophy and associated bladder neck hypertrophy. We do not entirely agree with this concept. The demonstrable patency of the bladder neck on cysto-urethrography would indicate that bladder neck hypertrophy is not a significant factor. Bladder neck hypertrophy may occur along with detrusor hypertrophy as a result of uncontrolled nerve impulses from the isolated reflex centres in the stump of the spinal cord. This hypertrophy however does not imply obstruction. The lack of success with bladder neck resection in patients who subsequently had successful external sphincterotomy would support this contention (Table VII).

In our series sphincterotomy was successful in restoring effective long term voiding in 74 per cent. of patients. The best results were achieved when the cystometrogram demonstrated a reflex bladder and sphincterogram a hypertonic external sphincter. The sphincter pressure need not be higher than the maximal detrusor spike to abort the bladder's ability to empty completely. Our success rate in reflex bladders was 86 per cent. The non-reflex bladder, since it does not generate a voiding contraction, will be less likely to empty even in the face of decreased resistance. The poorest results are expected in the non-reflex bladder in patients with high lesions who are thereby also deprived of the Crede manoeuvre (Table V). That external sphincterotomy produces a significant decrease in the readings of the post-operative sphincterogram is objective evidence of the decrease in urethral resistance to voiding. This lowered resistance can also be inferred from the disappearance of high pressure reflux in greater than one-half of the patients who had demonstrated reflux pre-operatively.

Failures should be subject to re-evaluation and undergo a second procedure, especially if reflex contractions are noted on the cystometrogram and if the sphincter pressures remain elevated. This can be appreciated from our 7I per cent. success rate with repeat sphincterotomies. Several causes for failure should be considered. The undermined prostate may present the sole obstruction to voiding. Malament noted a high incidence of this complication which may be due to his technique of starting the lateral incisions at the bladder neck rather than just proximal to the verumontanum, thereby undermining the prostatic lobes. Stricture and benign prostatic hypertrophy should be considered in the initially successful procedure which later fails. Incomplete division of the striated musculature of the external sphincter may also result in failure. It has been demonstrated that the external sphincter is not anatomically confined between the inferior and superior fascia of the urogenital diaphragm. Bundles of striated musculature have been demonstrated extending along the antero-lateral aspect of the prostatic urethra to the trigone (Manley, 1966). Striated musculature has been demonstrated to surround the distal portion of the prostatic urethra and has been termed the para-urethral sphincter (Murch, 1967). Perhaps failure to divide these bundles of striated muscle in the prostatic urethra may be an explanation for the occasional post-sphincterotomy failure. However, while the success of sphincterotomy may result in part from the division of the muscles of the external sphincter, we feel another factor to be of greater importance. We suggest that after incisional healing takes place fixation of the prostato-membranous urethra occurs. This fixed tube or conduit eliminates the obstructing effect of the asynchronous contractions of the external sphincter and pelvic musculature and thereby lowers urethral resistance. Peterson attributed post-prostatectomy incontinence to scarring and rigidity of the external sphincter (Peterson, 1967). Resection of 
scarred areas restored sphincter function in his series. Our incisions may result in similar rigidity and loss of function of the membranous urethra.

\section{SUMMARY}

External sphincterotomy, a procedure for lowering urethral resistance in the neurogenic bladder so as to restore efficient voiding and eliminate catheter drainage, is described. The technique is simple, the morbidity low and the success rate is high. It is most useful in the reflex upper motor neuron bladder, but should be considered in all catheter-bound neurogenic bladders. As multiple procedures may be required failures should be re-evaluated. Our experience with 173 operations on I5O patients is reviewed.

\section{RÉSUMÉ}

La description de la spinctérotomie du sphincter externe, qui est un procédé pour diminuer la résistance urétrale dans les cas de vessie neurogène, est donnée. Il s'agit de rétablir une miction efficace et d'éliminer le drainage par sonde. La technique est simple. La morbidité est basse et le taux de succès est élevé. Cette procédure est très utile dans les vessies de type central mais devrait, par ailleurs, être considérée dans tous les cas de vessies neurogènes drainées par sonde. Comme plusieurs interventions peuvent être nécessitées, les échecs de ces interventions doivent être réévalués. Notre expérience sur I73 opérations chez I 50 malades est passée en revue.

\section{ZUSAMMENFASSUNG}

Es werden Erfahrungen mit der externen Sphinkterotomie berichtet. Diese Operation dient der Verringerung des urethralen Widerstandes, der Widerherstellung erfolgreicher Miktion und der Ausschaltung der Katheter Drainage. Die Technik ist einfach, die Morbidität gering und die Erfolgsrate hoch. Die Operation ist besonders erfolgreich in der Behandlung der supra-nukleären Blase, sollte aber in allen Formen der neurogenen Blase angewandt werden, wo Katheterisierung notwendig ist. Es werden 173 Operationen an I50 Patienten analysiert.

\section{REFERENCES}

Ascoli, R. R. (1967). Radiological study of the vesical neck in paraplegia secondary to spinal cord injury. Paraplegia, 4. 235.

Baumrucker, G. O. (I948). Management of the paralyzed bladder. Arch. Surg. 56, 484.

Currie, R. J., Bilbisi, A. A., Shiebler, J. C. \& Bunts, R. C. (I970). External sphincterotomy in paraplegics: Technique and results. F. Urol. 103, 64.

DAMANSKI, M. (I96I). Cysto-urethrography in paraplegia: Its practical application. Brit. F. Urol. 33, 67.

Donovan, H. (I 947). Care of the urinary tract in paraplegic patients: Review of 82 cases. Lancet, $\mathbf{r}, 5 \mathrm{I} 5$.

EmANUEL, M. (1963). A new dynamic catheter-type sphincterometer. F. Urol. 90, 237.

EMMETT, J. L. \& DUNN, J. H. (I946). Transurethral resection in the surgical management of cord bladder. Surg., Gynec., and Obst. 43, 597.

Emmett, J. L., DAUT, R. V.\& DUNN, J. H. (I948). Role of the external urethral sphincter in the normal bladder and cord bladder. F. Urol. 59, 439.

Hutch, J. A. (1967). A new theory of the anatomy of the internal urinary sphincter and the physiology of micturition. IV. The urinary sphincteric mechanism. F. Urol. 97, 705 .

Lapides, J., Ajemian, E. P., Stewart, B. H., Breakey, B. A. \& Lichtwardt, J. R. (I960). Further observations on the kinetics of the urethrovesical sphincter. $\mathcal{F}$. Urol. 84, 86.

Malament, Maxwell. Personal communication. 
Manley, C. B. (I966). The striated muscle of the prostate. F. Urol. 95, 234.

O'FlynN, J. D. (I972). External sphincterotomy for the relief of outlet obstruction in neurogenic bladder. Paraplegia, 10, 29.

Peterson, R. A. (1967). Plastic repair of the external urinary sphincter: A new technique for correction of postoperative incontinence in men. F. Urol. 97, I050.

Ross, J. C., Gibbon, N. O. \& Damanski, M. (I958a). Division of the external urethral sphincter in the treatment of the paraplegic bladder. Brit. F. Urol. 30, 204.

Ross, J. C., Damanski, M. \& GibBon, N. O. (I958b). Resection of the external sphincter in the paraplegic-preliminary report. F. Urol. 79, 742 .

Ross, J. C., Gibbon, N. O. \& Damanski, M. (I967). Division of the external sphincter in the treatment of the neurogenic bladder. Brit. F. Surg. 54, 627.

SNYTHE, C. A. (1966). External sphincterotomy in the management of the neurogenic bladder: A preliminary report. F. Urol. 96, 3 Iо. 